\title{
Gene Expression Related to Steviol Glycoside Synthesis Produced in Stevia rebaudiana (Bert.) Shoot Culture Induced with High Far-Red LED Light in TIS RITA ${ }^{\circledast}$ Bioreactor System
}

\author{
Agustine Christela Melviana ${ }^{1}$, Rizkita Rachmi Esyanti ${ }^{1 *}$, Roy Hendroko Setyobudi ${ }^{2}$, Maizirwan Mel $^{3}$, \\ Praptiningsih Gamawati Adinurani ${ }^{4}$ and Juris Burlakovs ${ }^{5}$
}

${ }^{1}$ School of Life Sciences and Technology, Bandung Institute of Technology, Jl. Ganesa 10, Bandung 40132, West Java-Indonesia; ${ }^{2}$ Department of Agriculture Science, Postgraduate Program, University of Muhammadiyah Malang, Jl. Raya Tlogomas No. 246, Malang, 65145, East Java, Indonesia; ${ }^{3}$ Department of Biotechnology Engineering, International Islamic University Malaysia, Jl. Gombak, 53100, Selangor, Malaysia; ${ }^{4}$ Department of Agrotechnology, Merdeka University of Madiun, Jl. Serayu No.79, Madiun 63133, East Java, Indonesia, ${ }^{5}$ Department of Water Management, Estonian University of Life Sciences, Tartu, Estonia; Friedrich Reinhold Kreutzwaldi 1a, 51014 Tartu, Estonia.

\begin{abstract}
Steviol glycosides contained in Stevia leaves have considerable potential uses for the natural sweetener industry due to it's antidiabetic properties, hence a large number of plant source is required to supply the industry. To overcome the hindrances in the propagation of Stevia plants using in vivo methods, an alternative technique of propagation using in vitro methods is needed. The micropropagation method with the RITA $^{\circledR}$ (Recipient for Automated Temporary Immersion System) is used in the production of a large amount of stevia biomass in approximately a short period. The forming of flowers is one of the limiting factors interfering with the metabolite production, as the content of steviol glycoside will decrease after plant flowering dramatically. This mechanism happened because steviol glycoside synthesis and flowering process share the same precursor. However, this interfering factor could be inhibited by using a high-red LED induction to delay the flowering stage, which may contribute to higher biomass and glycoside concentrations through greater system productivity. Hitherto, there was no significant study about the effect of far-red LED induction to improve the steviol glycoside content of Stevia plants, particularly at the molecular level. This research was therefore performed in the TIS RITA ${ }^{\oplus}$ bioreactor system to evaluate the effect of far-red LED induction towards biomass growth, multigene expression related to steviol glycosides, and its derivatives, and also the metabolites produced in $S$. rebaudiana plant. The result showed that the increment of biomass and gene expressions (ent-KO, ent-KS, ent-KAH13, UGT85C2, UGT74G1, and UGT76G1) in high far-red LED RITA $^{\oplus}$ was higher compared with control RITA ${ }^{\circledast}$. To conclude, the system with a far-red LED induction in TIS RITA ${ }^{\otimes}$ was proven to give a positive effect towards stevia shoots growth and greater metabolites production (stevioside and rebaudioside-A) up to $37.15 \%$ and $22.99 \%$, respectively.

Received | August 08, 2020; Accepted | December 08, 2020; Published | January 03, 2021

*Correspondence | Rizkita Rachmi Esyanti, School of Life Sciences and Technology, Bandung Institute of Technology, Jl. Ganesa 10, Bandung 40132, West Java-Indonesia; Email: rizkita@ sith.itb.ac.id

Citation | Melviana, A.C., R.R. Esyanti, R.H. Setyobudi, M. Mel, P.G. Adinurani and J. Burlakovs. 2021. Gene Expression related to steviol glycoside synthesis produced in Stevia rebaudiana (Bert.) shoot culture induced with high Far-Red LED light in TIS RITA ${ }^{\circledR}$ bioreactor system. Sarhad Journal of Agriculture, 37(1): 1-8.

DOI | http://dx.doi.org/10.17582/journal.sja/2021/37.1.1.8

Keywords | Diabetes prevention, Improve the steviol glycoside, In vitro method, Micropropagation, Natural sweetener
\end{abstract}




\section{Introduction}

$\mathrm{T}$ he percentage of individuals with type 2 diabetes mellitus (T2DM), which is around $85 \%$ of the population, is primarily calculated by persons with type 2 diabetes mellitus (Standl et al.,2019). The rising prevalence of T2DM in the world is mainly caused by the consumption of foods and drinks containing high levels of artificial sweeteners (AS) such as sucralose, aspartame, saccharin, and acesulfame potassium. Currently, AS is widely available and utilized as calorie-free sugar replacements, although these sweeteners are known as non-nutritive sweeteners which raised the incidence of T2DM in Indonesia. The World Health Organization estimates that Indonesia is the fourth highest diabetic community in the world following India, China, and the United States (Shaw et al., 2010). Therefore, the exploration of low calorie natural sweeteners is important for the country, one of them is by exploring Stevia rebaudiana (Bert.) plant, which is well recognized for its potential as antihyperlipidemic and insulinotropic effects.

Stevia is an herbal perennial shrub which cultivated in Indonesia because this plant produces diterpene glycosides including stevioside, steviolbioside, rebaudiosides (A, B, C, D, E) and dulcoside A (Ahmad and Ahmad, 2018). The popular herb S. rebaudiana is an ideal natural sugar substitute renowned for its major sweet constituents (stevioside and rebaudioside A) that provides a sweet taste 300 times sweeter than sugar (Kobus and Gramza, 2015). The plant metabolites has also been shown to be a major antidiabetic, as the intake of stevia extract decreases significantly the blood glucose and glycosylated (HbA1c), whereas the extract greatly increases the amount of insulin and liver glycogen (Ahmad and Ahmad, 2018). Furthermore, stevia has been applied as substitutes for saccharose and treatment of diabetes mellitus, obesity, hypertension, and caries prevention by stimulating the secretion of insulin by beta-type cells of the pancreas (Goyal et al., 2010). With the health benefits offered by these plants to reduce the prevailing of global's T2DM, stevia needs to be propagated in large quantities and a short time in Indonesia.

Stevia is usually propagated by the conventional method, but this method was inefficient due to the low viability of its seeds due to self incompatibility
(Ramírez and Iglesias, 2016), large variability in levels and composition of stevioside (Anbazhagan et al., 2010), and less than $10 \%$ germination rates (Razak et al., 2014). In vitro method provides an efficient way to tackle these problems and this method is capable of growing a large number of stevia plants and less time consuming compared with the conventional methods. According to Melviana et al. (2020), S. rebaudiana shoots cultivated in RITA $^{\oplus}$ (Recipient for Automated Temporary Immersion System) bioreactor with immersions of 30 min every $6 \mathrm{~h}$ could enhance the biomass by up to $71.11 \%$ and reached higher productivity. By using a RITA ${ }^{\circledR}$ bioreactor, the system could be more efficient to obtain a higher biomass and secondary metabolite production. Therefore, multiplication with large quantities of stevia biomass in relatively short periods and less subculture process can be achieved by using TIS RITA ${ }^{\circledast}$ bioreactor.

Another problem in the cultivation of stevia is limited its harvesting time due to the flowering phase (Ceunen et al., 2012). The steviol glycoside content will decrease significantly if the stevia plant has flowered. This phenomenon occurs because the metabolite pathway for the production of steviol glycosides and flowering process has the same precursor, ent-kaurene acid (Ceunen and Geuns, 2013). A red/far-red (R/FR) 1.22 Light-Emitting Diodes (LED) light induction to interrupt the night cycle or treatment at the end of the light cycle (end of day/ EOD) in S. rebaudiana plant was proven to give a positive effect on delaying the generative phase of plants and increased the genes expression related to steviol glycoside synthesis. A far-red rich LED exposure of $20 \mathrm{~min}$ to interrupt the night cycle of plants obtained a higher transcription factor for steviolmonoside and rebaudioside- $A$, in comparison to plants without any light induction. The UGT85C2 gene in high far-red condition was approximately 5.7 higher compared with the expression in fluorescent condition without any interruption (control). Besides, the transcription of $U G T 76$ G1, the gene which encodes the production of rebaudioside from stevioside precursor also increased up to 92.9 times compared with control (Yoneda et al., 2017).

This study aims to evaluate the expression of genes associated with the synthesis pathway of steviol glycoside production (ent-KO, ent-KS, ent-KAH13, UGT85C2, UGT74G1, and UGT76G1) from shoot culture of $S$. rebaudiana which cultivated in TIS RITA ${ }^{\oplus}$ 
bioreactor system with high far-red LED exposure. In Stevia, the metabolite production begins when geranylgeranyl diphosphate (GGDP) is converted into steviol by the consecutive action of four enzymes namely copalyl diphosphate synthase (CPPS), kaurene synthase (KS), kaurene oxidase (KO) and kaurenoic acid hydroxylase (KAH). For the first, geranyl geranyl diphosphate (GGPP) is transformed to ent-copalyl diphosphate by copalyl diphosphate synthase (CPS), and then ent-copalyl diphosphate is cyclized to entkaurene by kaurene synthase (KS) encoded by ent-KS genes. Then, ent-kaurene is oxidized and hydroxylated to become kauroneic acid by kaurene oxidase (KO) which is encoded by the ent-KO genes. At last, entKAH13 encoded the synthesis of kaurenoic acid 13-hydroxylase (KAH) which responsible to convert kauroneic acid into steviol (Brandle and Telmer, 2007). UGT85C2, UGT74G1, and UGT76G1 are UDPglycosyltransferases (UGT) that catalyze sugartransferring reactions to add glucose to the steviol basic skeleton. UGT85C2 catalyzes the synthesis of steviolmonoside from steviol, UGT74G1 catalyzes the synthesis stevioside from steviolbioside, and last, UGT76G1 catalyzes and add glucose to stevioside to form rebauidioside-A (Mohamed et al., 2011).

\section{Materials and Methods}

\section{Culture medium preparation}

Two types of media, semi solid media and liquid media were used in all stevia micropropagation. The semi-solid media is used for initiation and subculture processes, while the liquid medium is used for the pre-acclimation process with thin layer systems and also for bioreactors. All mediums used $30 \mathrm{~g} \mathrm{~L}^{-1}$ sucrose, Kinetin as plant growth hormone with $1 \mathrm{mg}$ $\mathrm{kg}^{-1}$ concentration (Melviana et al., 2021). The halfstrength MS salts without a gelling agent were used in pre-acclimation and bioreactor medium. The $\mathrm{pH}$ of each medium was adjusted to 5.8 and autoclaved at $121^{\circ} \mathrm{C}$ for $15 \mathrm{~min}$. Then, the sterilized media was added by $200 \mathrm{mg} \mathrm{kg}{ }^{-1}$ Augmentin for additional prevention of bacterial contamination.

\section{Shoot culture in RITA $^{\oplus}$ bioreactor}

Bioreactors were assembled and the airflow was adjusted by an automatic timer with $30 \mathrm{~min}$ immersion time, scheduled every 6-h (Melviana et al., 2020). The control bioreactor (RITA ${ }^{\circledast} 1$ ) was exposed to 2000 $\mathrm{lx}$ to $2500 \mathrm{~lx}$ ordinary white fluorescent lamps for $16 / 8 \mathrm{~h}$ daily photoperiod. While high far-red ratio bioreactor $\left(\mathrm{RITA}^{\oplus} 2\right)$ treated with $4800 \mathrm{~lx}$ to 6000 lx R:FR LED light exposure $(\lambda=660 \mathrm{~nm}$ and $730 \mathrm{~nm}$, with $98.9 \mu \mathrm{mol} \mathrm{m} \mathrm{m}^{-2} \mathrm{~s}^{-1}$ of High far-red) for $1 \mathrm{~h}$ during the night period. The irradiance of far-red light to the culture was adjusted with a spectroradiometer (LI1800, LI-COR, Inc., USA).

\section{$R N A$ isolation and $c D N A$ synthesis}

Every apical shoot from bioreactor RITA $^{\circledR}$ was collected, cut, and processed for RNA isolation. RNA was isolated using the $S V$ Total RNA Isolation System (Promega) kit, according to the manufacturer's instructions. Only RNA samples of great purity $\left(\mathrm{A}_{260} /\right.$ $\left.\mathrm{A}_{280}>1.70\right)$ were used in cDNA synthesis. cDNA synthesis was processed by using $i \operatorname{Script}^{T M} c D N A$ Synthesis kit and protocol.

\section{Polymerase Chain Reaction (PCR) and Quantitative- Polymerase Chain Reaction ( $q P C R$ )}

Every $1 \mu \mathrm{L}$ cDNA was amplified by using $A B I$ Veriti thermal cycler to obtain the gene fragment, i.e: EntKS, Ent-KO, Ent-KAH 13 UGT85C2, UGT46G1, UGT66G1, and $\beta$-Actin (Reference gene). The amplification process used was GoTaq ${ }^{\oplus}$ Green Master Mix reagents from Promega (Catalog No. M7122). The amplification process used specific primers pre-designed by using NCBI and Primer 3+ (Table 1). Furthermore, the quantification of genes related to steviol glycosides production used SsoFast ${ }^{\mathrm{TM}}$ Evagreen $^{\oplus}$ (No. catalog\# 172-5200) dyes. qPCR assays were done in Bio-Rad CFX iCycler ${ }^{\oplus} 96^{\mathrm{TM}}$ Thermal Cycler (USA) and integrated with $\mathrm{iQ}^{\mathrm{TM}} 5$ Real-Time PCR detection system (USA). Data from the Real-Time PCR (qPCR) was analyzed using the relative method ( $\mathrm{Li}^{-}$ vak and Schmittgen, 2001). qPCR quantification results were obtained in the form of $\mathrm{Ct}$ values where the ${ }^{\Delta} \mathrm{Ct}$ value for every gene was normalized to $\beta$-actin and subsequently normalized to the value obtained for the control using the $2^{-\Delta \Delta C T}$ method.

\section{Metabolites analysis}

The accumulation of stevioside and rebaudioside-A of $S$. rebaudiana in vitro shoot culture were analyzed using HPLC (High-Performance Liquid Chromatography) with methanol: water (8:2) eluent

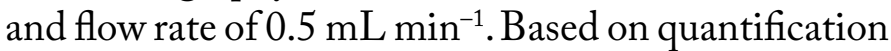
by calibration adjustment using the pure standard of stevioside solution (Sigma Aldrich, USA), stevioside compounds of $S$. rebaudiana shoots were detected at $10.4 \mathrm{~min}$ to $10.6 \mathrm{~min}$, in contrast, rebaudioside-A were detected at $6.6 \mathrm{~min}$ to $9.9 \mathrm{~min}$. 
Table 1: The primer design of oligonucleotides used to amplify genes related to the synthesis of steviol glycoside.

\begin{tabular}{|c|c|c|c|c|}
\hline Name & \multicolumn{2}{|c|}{ Forward/Reverse } & Amplicon (base pair) & $\mathrm{T}_{\mathrm{m}}\left({ }^{\circ} \mathrm{C}\right)$ \\
\hline \multirow[t]{2}{*}{ Ent-KS } & $\mathrm{F}$ & CTTGACGGGGGTACTGTTGT & \multirow[t]{2}{*}{198} & 57.00 \\
\hline & $\mathrm{R}$ & CAACGAACAACCACCAAGTG & & 54.60 \\
\hline \multirow[t]{2}{*}{ Ent-KO } & $\mathrm{F}$ & AGAAACACCGCATCCATAGG & \multirow[t]{2}{*}{195} & 54.80 \\
\hline & $\mathrm{R}$ & GTTTACCGCTAGCTCGGTTC & & 55.70 \\
\hline \multirow[t]{2}{*}{ Ent-KAH13 } & $\mathrm{F}$ & CCGACTCCATTCACCTTTGT & \multirow[t]{2}{*}{206} & 55.00 \\
\hline & $\mathrm{R}$ & ACTTGATGGGGATGAAGACG & & 54.50 \\
\hline \multirow[t]{2}{*}{ UGT85C2 } & $\mathrm{F}$ & CTTCGTCAACACCGACTTCA & \multirow[t]{2}{*}{203} & 55.00 \\
\hline & $\mathrm{R}$ & AACCGACAAGAACCCATCTG & & 55.00 \\
\hline \multirow[t]{2}{*}{ UGT74G1 } & $\mathrm{F}$ & CCACAGTAACACCACCACCA & \multirow[t]{2}{*}{172} & 57.30 \\
\hline & $\mathrm{R}$ & TTGTGAAGACCCAACGTGCT & & 57.10 \\
\hline \multirow[t]{2}{*}{ UGT76G1 } & $\mathrm{F}$ & ACTCCCCAAGCATTTGACAG & \multirow[t]{2}{*}{167} & 55.30 \\
\hline & $\mathrm{R}$ & CAACCAACCCACGAGCTATT & & 55.30 \\
\hline \multirow[t]{2}{*}{$\beta$-Actin } & $\mathrm{F}$ & CTTGATCTTGCTGGTCGTGA & 158 & 54.90 \\
\hline & $\mathrm{R}$ & GCGGTTTCAAGTTCTTGCTC & & 54.70 \\
\hline
\end{tabular}

Table 2: Biomass production in RITA ${ }^{\oplus}$ control and high Far-Red LED.

\begin{tabular}{lllllll} 
RITA $^{\infty}$ & \multicolumn{2}{l}{ Average initial mass $(\mathbf{g}) \pm$ SD } & \multicolumn{2}{l}{ Average final mass $(\mathrm{g}) \pm \mathrm{SD}$} & $\begin{array}{l}\text { Growth rate }(\mathrm{g} \\
\text { Bioreactor }\end{array}$ & $\begin{array}{l}\text { Productivity } \\
\left.\mathbf{( g .} \mathbf{L}_{\text {medium }}{ }^{-1} \mathbf{d}^{-1}\right)\end{array}$ \\
Control & $4.300 \pm 0.000$ & $0.610 \pm 0.000$ & $12.375 \pm 0.134$ & $1.395 \pm 0.021$ & $0.039 \pm 0.001$ & $0.150 \pm 0.006$ \\
High far-red LED & $4.300 \pm 0.000$ & $0.610 \pm 0.000$ & $14.820 \pm 0.127$ & $1.904 \pm 0.055$ & $0.054 \pm 0.001$ & $0.246 \pm 0.011$
\end{tabular}

\section{Results and Discussions}

\section{Shoot multiplication in RITA $A^{\circledast}$ bioreactor}

$S$. rebaudiana shoots were then cultivated in $\mathrm{RITA}^{\oplus}$ bioreactor for $3 \mathrm{wk}$. According to Table 2, RITA ${ }^{\oplus}$ LED (exposed with high far-red light LED every $1 \mathrm{~h}$ on dark cycle) gave the highest multiplication of stevia shoots compared with RITA $^{\circledast}$ LED, with an average initial mass increase of shoots for RITA $^{\otimes}$ LED was $89.71 \% \pm 5.83 \%$, while RITA $^{\circledast}$ control (without any interruption of high far-red LED) only $76.90 \% \pm 4.85$ $\%$. The growth rate of S.rebaudiana cultivated in $\mathrm{RITA}^{\oplus}$ LED minutes was greater than $\mathrm{RITA}^{\oplus}$ Control (Figure 1). Results showed that the growth rate of $S$. rebaudiana in $\mathrm{RITA}^{\oplus} \mathrm{LED}$ was $0.054 \mathrm{~g} \pm 0.001 \mathrm{~g}$ DW $\mathrm{d}^{-1}$ with doubling time $(\mathrm{dt}) 12.793 \mathrm{~d} \pm 0.326 \mathrm{~d}$ while in RITA ${ }^{\oplus}$ Control was $0.039 \mathrm{~g} \pm 0.001 \mathrm{~g} \mathrm{DW} \mathrm{d}^{-1}$ with a dt $17.6 \mathrm{~d} \pm 0.553 \mathrm{~d}$. The observation of culture in the RITA $^{\oplus}$ bioreactor showed that 3 wk growth of culture in RITA $^{\oplus}$ high far-red LED system was better than RITA $^{\oplus}$ control system.

Analysis of the expression of genes associated with the synthesis pathway of steviol glycoside production RNA isolation needs to be done to determine the effect of high far-red LED light exposure on gene expression related to steviol glycosides synthesis i.e: ent-KO, ent-KS, ent-KAH13, UGT85C2, UGT74G1, and $U G T 76 G 1$. The results confirmed with the purity number of RNA, measured by using NanoDrop $(\lambda=$ $260 \mathrm{~nm}$ and $280 \mathrm{~nm})$. The best purity number of RNA was more than 1.8 by measuring the Optical Density method at $\lambda_{260 / 280} \mathrm{~nm}$ (Fleige and Pfaff, 2006). The result showed from eight samples (both controls and treatments), all RNA nearly had a good quality because the ratio $\lambda_{260 / 280}$ was in the theoretical range. The average of RNA integrity for the control was $1.84 \pm 0.08$, while the quality for the treatment sample was $1.89 \pm 0.07$. Based on the results of RNA isolation, the eight samples yielded two bands of RNA and the quality test results show that the RNA also can be used for the cDNA synthesis process.

Amplification of genes related to steviol glycosides synthesis from cDNA of $S$. rebaudiana shoots was performed to confirm the presence of amplicon bands of the target genes before the qPCR process. Amplification of genes using PCR methods produced gene fragments corresponding to their respective size, which were about 198 base pair (bp) ent-KS, $195 \mathrm{bp}$ for ent-KO, $206 \mathrm{bp}$ for ent-KAH13, $203 \mathrm{bp}$ for $U G T 85 C 2,172 \mathrm{bp}$ for the UGT7461, and $167 \mathrm{bp}$ 
for UG7661 gene. Amplification was also performed on the house-keeping gene, $\beta$-Actin, with amplicons size about $158 \mathrm{bp}$. The selection of the reference gene was based on the most stable expression value $(\mathrm{Ct})$ of $\beta$-actin in $S$. rebaudiana samples when compared to the expression of the ubiquitin, GAPDH, and $18 \mathrm{~S}$ rRNA genes (Modi et al., 2014).

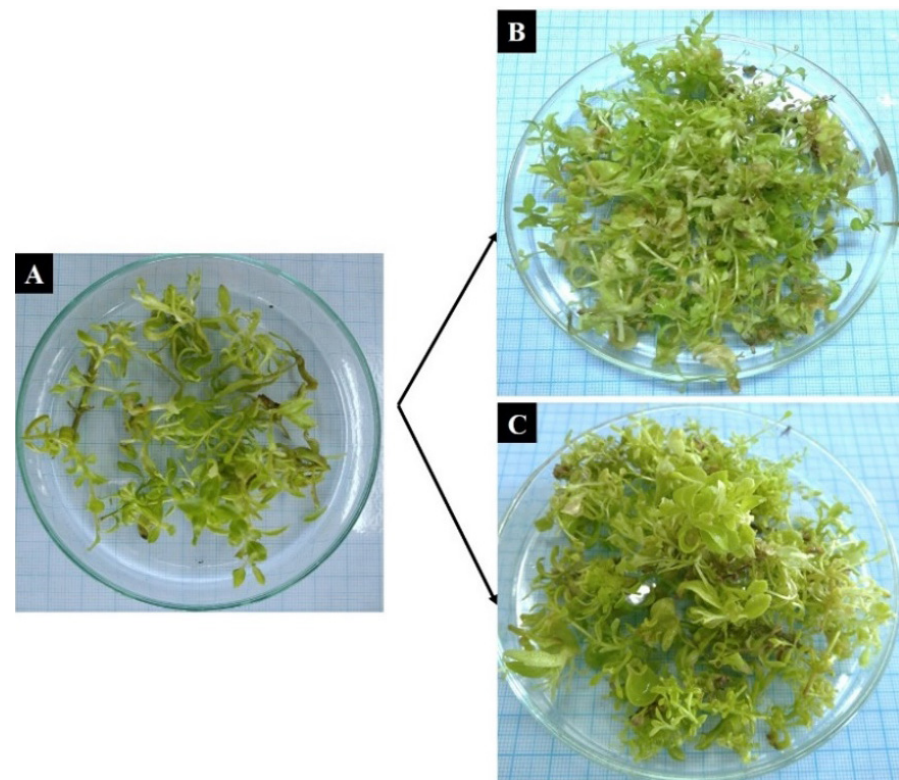

Figure 1: Shoots before and after cultivation in RITA ${ }^{\circledR}$ bioreactor: (A) Day 0; (B) Days 21 for RITA ${ }^{\oplus}$ Control (No Exposed with High Far-Red LED Light); and (C) Days 21 for RITA ${ }^{\boxplus}$ LD (Exposed with High Far-Red Light LED for 1 hour during night cycle).

The amplification process was carried out at various temperature ranges $[(54.4 ; 55.4 ; 56.3 ; 57.7 ; 58.8 ; 59.5$ and 60$){ }^{\circ} \mathrm{C}$ ] to determine the optimum annealing temperature. It was found that at $58.8{ }^{\circ} \mathrm{C}$, all genes were well amplified and the quality of DNA bands was better compared to another annealing temperatures, so $58.8^{\circ} \mathrm{C}$ was chosen to be the annealing temperature in $\mathrm{qPCR}$.

The results of the analysis using the qPCR method indicate that there was a difference in the relative expression level of genes related to steviol glycoside synthesis between RITA ${ }^{\circledast}$ Control group and RITA ${ }^{\oplus}$ high far-red LED group. In the RITA $^{\oplus}$ LED treatment, the accumulation of all genes related to steviol glycosides synthesis improved (up-regulated) (Figure 2). The results showed that increased expression levels occurred in the ent-KO genes $(\sim 1.16$ times), ent-KS ( 1.27 times), ent-KAH $13(\sim 1.28$ times), UGT85C2 ( 1.25 times), UGT74G1 ( 1.77 times) and $U G T 76 G 1$ ( 1.14 times) on $S$. rebaudiana shoots which cultivated in RITA $^{\oplus}$ LED bioreactors. The highest increment which statistically significant by the t-test method was the UGT74G1 expression. This gene encoding the steviolside production from steviolbioside precursors.

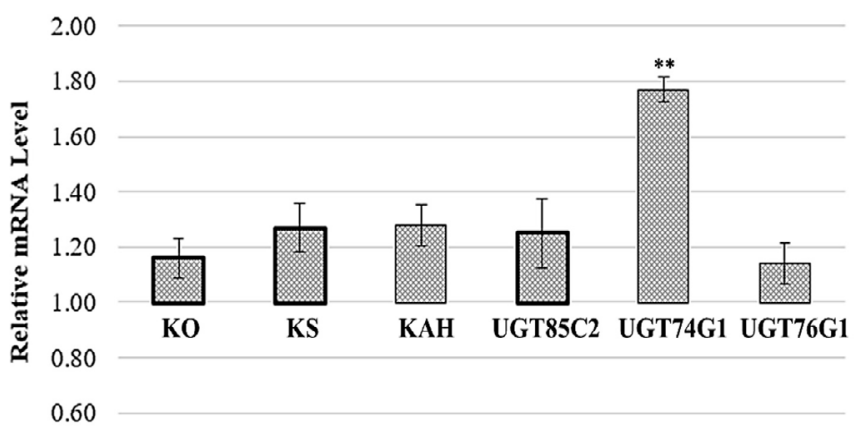

Figure 2: Gene expression profiles related to steviol glycosides synthesis of $S$. rebaudiana shoot cultivated in RITA bigh far-red LED bioreactors compared with control (as a baseline with 1 relative $m R N A$ level); (**: significantly different by student's test with $p$-value $<0.01$ ).

Stevia plants grow as a short lived perennial and to delay the flowering process, plants need to be given the addition of a longer light cycle (Ceunen and Geuns, 2013). In this experiment, stevia plants were treated with long-term plant conditions (much longer lighting compared to dark cycles, i.e $16 \mathrm{~h}$ light and $8 \mathrm{~h}$ of darkness). In addition, environmental manipulation is carried out to slow down the flowering process in S.rebaudiana shoot culture by interrupting the night cycle with a high far-red LED. Light perception in all plants is mediated by the red/far-red light-receptor and blue light-receptor phytochromes (phyA-E). Furthermore, the phytochrome which depending on the light intensity present in two different forms, red-light absorbed (Pr) and far-red light absorbent (Pf). Red light stimulates phytochrome by converting Pr to Pfr while far-red light reduces the amount of active form by converting Pfr back into $\operatorname{Pr}$ (Endo et al., 2013).

One of the receptors for red or far-red light in the plant is Phytochrome B (phyB) which is able to enter the nucleus and regulate the transcription of the key of the flowering factor, CONSTANS (CO) (Iñigo et al., 2012). The elevation in the level of $\mathrm{CO}$ protein, in turn, up-regulates the expression of flowering Locus $\mathrm{T}$ (FT), which encodes the mobile florigen and accelerate the flowering process (Higuchi, 2018). Gibberellin, an endogenous plant hormone that are essential flowering regulators and unfortunately this hormone synthesized through many steps from geranylgernayl diphosphate, and ent-copalyl diphosphate synthase (CPS), and ent-kaurene 
synthase (KS) (Guan et al., 2019). It can be seen that $\mathrm{KS}$ for gibberellin production is also the precursor for steviol glycoside synthesis, hence, to get more KS for steviol glycoside and its derivatives synthesis then the flowering process in stevia needs to be delayed. By minimizing the number of active phytochrome B which activates the genes related to flowering, it was expected that flowering can be delayed by inactivating the PhyB (Hajdu et al., 2015). As a result, if the flowering process can be repressed so ent-kaurene acid precursors will lead to the production of steviol glycosides rather than produced gibberellin hormone for flowering.

The main purpose of interruptions by high far redLED in the dark cycle of plants cultivated in RITA ${ }^{\oplus}$ TIS bioreactor was to increase the expression of entKAH13 genes indirectly. A high far red-LED LED interruption during the night period (1.22 Pfr ratio) will make the plant $B$ phytochrome inactive and increased the expression of ent-KAH13 genes. If the level of expression of ent-KAH13 genes was higher, it means that more acid compounds will be produced and these compounds may become precursors for the production of steviosides and rebaudiosides-A. Basically, the level of gene expression cannot be directly correlated with the amount of metabolite produced, because there is a post-translational phenomenon that may affect the protein profile. However, an effort to produce more precursor of the steviol glycosides (kaurene acid), has been successfully carried out with a high far-red LED light exposure to interrupted the dark cycle of stevia plants had a positive effect on the deceleration of the vegetative phase to the generative phase (flowering phase) (Yoneda et al., 2017).

\section{Metabolites analyses}

The stevioside content of $\mathrm{RITA}^{\oplus} \mathrm{Control}$ amounted to only $6.956 \mu \mathrm{g} \mathrm{g}^{-1} \pm 0.576 \mu \mathrm{g} \mathrm{g}^{-1}$, while the high far-red RITA $^{\oplus}$ LED bioreactor reached $11.067 \mu \mathrm{g} \mathrm{g}^{-1} \pm 0.383$ $\mu \mathrm{g} \mathrm{g}^{-1}$. A high far-red LED interruption in the night cycle proven to increase the percentage of stevioside accumulation per plant up to four times compared with plants without red light LED interruption (Yoneda et al., 2017). The results showed the same pattern where there was an increase of stevioside accumulation in RITA $^{\oplus}$ far-red LED bioreactor by $37.15 \%$ when compared with RITA $^{\oplus}$ Control. The rebaudioside-A content of RITA $^{\oplus}$ Control amounted only $4.624 \mu \mathrm{g} \mathrm{g}^{-1} \pm 0.340 \mu \mathrm{g} \mathrm{g}{ }^{-1}$, while the high far-red $\mathrm{RITA}^{\otimes}$ LED bioreactor reached $6.004 \mathrm{~g} \mathrm{~g}^{-1} \pm 0.013 \mathrm{~g}$ $\mathrm{g}^{-1}$. In other words, rebaudioside-A content increased up to $22.98 \%$ in RITA $^{\circledR}$ high far-red LED bioreactor when compared with RITA $^{\oplus}$ Control.

\section{Conclusions and Recommendations}

The biomass in far-red LED RITA $^{\oplus}$ increased by $1.702 \mathrm{~g} \pm 0.114 \mathrm{~g}$ compared to control RITA ${ }^{\oplus}$ control (no exposure) which only increased by $0.953 \mathrm{~g} \pm$ $0.093 \mathrm{~g}$. In conjunction with the increase of biomass, the productivity of $S$. rebaudiana in the far-red LED RITA $^{\circledast}$ system was 0.246 g.L medium $^{-1} \mathrm{~d}^{-1}$, whereas in Control RITA ${ }^{\oplus}$ was only 0.150 g. medium $^{-1} \mathrm{~d}^{-1}$. Plantlet exposed to high far-red light LED exhibited an increment of expression levels on all genes related to steviol glycoside synthesis. The stevioside and rebaudioside-A content analyzed in HPLC were 37.15 $\%$ and $22.99 \%$ higher compared to the planlet cultured in RITA $^{\circledast}$ controls. The natural sweetener industry always produces stevioside and rebaudioside-A, so it can be concluded that by applying far-red LED light in the middle of the night cycle of plants, this system provides an easy and inexpensive way to increase these two metabolites production. This could be an easy way to prolong the growing season on the Stevia plantations in Indonesia: by using the specific far-red LED then the number of harvests could be reduced while the industry may effectively increase the leaf biomass and metabolites yield.

\section{Acknowledgements}

The authors would like to thank Asahi Glass Foundation for partly funding the research.

\section{Novelty Statement}

Various studies have shown that the propagation can be improved by using tissue culture and also environment manipulation by using high far-red induction. Unfortunately, the previous study never reported using these two techniques at the same time to produce greater natural sweetener metabolites. This study is the first study to collaborate on the micropropagation technique which is optimized in TIS RITA ${ }^{\oplus}$ bioreactor with the addition of high farred LED induction. As a result, there was a significant increment for biomass growth, gene expression, and metabolites production in $S$. rebaudiana culture. This article is the first study that succeeds to enhance the gene expression related to steviol glycoside 
synthesis from 1.16 up to 1.8 fold and followed with metabolites production which higher by $22 \%$ to $38 \%$. Furthermore, the study is the first article that provides an easy and inexpensive way to increase the production of sweetener metabolites by applying farred LED light in the middle of the night cycle of S. rebaudiana shoot culture which was cultivated in TIS RITA $^{\oplus}$ bioreactor.

\section{Author's Contribution}

Agustine Christela Melviana: Concepts, design, literature search, experimental studies, data acquisition, and manucript preparation.

Rizkita Rachmi Esyanti: Concepts, design, definition of intellectual content, and literature search.

Roy Hendroko Setyobudi: Definition of intellectual content, literature search, manuscript editing, manuscript review, and guarantor.

Maizirwan Mel: Definition of intellectual content, literature search, manuscript review, and guarantor.

Praptiningsih Gamawati Adinurani: Definition of intellectual content, literature search, and statistical analysis.

Juris Burlakovs: Definition of intellectual content, literature search, and manuscript review.

\section{Conflict of interest}

The authors have declared no conflict of interest.

\section{References}

Ahmad, U. and R.S. Ahmad. 2018. Anti diabetic property of aqueous extract of Stevia rebaudiana Bertoni leaves in Streptozotocin-induced diabetes in albino rats. BMC Complement. Altern. Med., 18(1): 1-11. https://doi. org/10.1186/s12906-018-2245-2

Anbazhagan, M., M. Kalpana, R. Rajendran, V. Natarajan and D. Dhanavel. 2010. In vitro production of Stevia rebaudiana Bertoni. Emir. J. Food Agric., 22(3): 216-222. https://doi. org/10.9755/ejfa.v22i3.4891

Brandle, J.E. and P.G. Telmer. 2007. Steviol glycoside biosynthesis. Phytochemistry, 68(14): 1855-1863. https://doi.org/10.1016/j. phytochem.2007.02.010

Ceunen, S. and J.M.C. Geuns. 2013. Influence of photoperiodism on the spatio-temporal accumulation of steviol glycosides in Stevia rebaudiana (Bertoni). Plant Sci., 198: 72-82. https://doi.org/10.1016/j.plantsci.2012.10.003

Ceunen, S., S. Werbrouck and J.M.C. Geuns. 2012.

Stimulation of steviol glycoside accumulation in Stevia rebaudiana by red LED light. J. Plant Physiol., 169(7): 749-752. https://doi. org/10.1016/j.jplph.2012.01.006

Endo, M., Y. Tanigawa, T. Murakami, T. Araki and A. Nagatani. 2013. Phytochrome dependent late-flowering accelerates flowering through physical interactions with phytochrome B and Constans. Proc. Natl. Acad. Sci. U.S.A. 110(44): 18017-18022. https://doi.org/10.1073/ pnas. 1310631110

Fleige, S., and M.W. Pfaffl. 2006. RNA integrity and the effect on the real-time qRT-PCR performance. Mol. Aspects Med., 27(23): 126-139. https://doi.org/10.1016/j. mam.2005.12.003

Goyal, S.K., Samsher and R.K. Goyal. 2010. Stevia (Stevia rebaudiana) a bio-sweetener: A review. Int. J. Food Sci. Nutr., 61(1): 1-10. https://doi. org/10.3109/09637480903193049

Guan, Y-r., X. Jing-qi, X. Yu-qian, Y. Ruo-wen, W. Shun-li and Z. Xiu-xin. 2019. Effect of exogenous GA3 on flowering quality, endogenous hormones, and hormone and flowering associated gene expression in forcing cultured tree peony (Paeonia suffruticosa). J. Integr. Agric., 18(6): 1295-1311. https://doi. org/10.1016/S2095-3119(18)62131-8

Hajdu, A., E. Ádám, D.J. Sheerin, O. Dobos, P. Bernula, A. Hiltbrunner, L. Kozma-Bognár and F. Nagy. 2015. High-level expression and phosphorylation of phytochrome B modulates flowering time in Arabidopsis. Plant J., 83(5): 794-805. https://doi.org/10.1111/tpj.12926

Higuchi, Y., 2018. Florigen and anti-florigen: Flowering regulation in horticultural crops. Breed. Sci., 68(1): 109-118. https://doi. org $/ 10.1270 /$ jsbbs. 17084

Iñigo, S., M.J. Alvarez, B. Strasser, A. Califano and P.D. Cerdán. 2012. PFT1, the MED25 subunit of the plant Mediator complex, promotes flowering through CONSTANS dependent and independent mechanisms in Arabidopsis. Plant J. 69(4): 601-612. https:// doi.org/10.1111/j.1365-313X.2011.04815.x

Kobus-Moryson, M. and A. Gramza-Michałowska 2015. Directions on the use of stevia leaves (Stevia rebauidana) as an additive in food products. Acta Sci. Pol. Technol. Aliment., 
14(1): 5-13. https://doi.org/10.17306/J. AFS.2015.1.1

Livak, K.J. and T.D. Schmittgen. 2001. Analysis of relative gene expression data using real time quantitative PCR and the $2-\Delta \Delta \mathrm{CT}$ method. Methods, 25(4): 402-408. https://doi. org/10.1006/meth.2001.1262

Melviana, A.C., R.E. Rizkita, M. Maizirwan and H.S. Roy. 2021. Biomass enhancement of Stevia rebaudiana Bertoni shoot culture in temporary immersion system (TIS) RITA $^{\circledR}$ bioreactor optimized in two different immersion periods. E3S Web Conf. 226(00007):1-9. https://doi. org/10.1051/e3sconf/202122600007

Modi, A., N. Litoriya, V. Prajapati, R. Rafalia and S. Narayanan. 2014. Transcriptional profiling of genes involved in steviol glycoside biosynthesis in Stevia rebaudiana Bertoni during plant hardening. Dev. Dyn., 243(9): 1067-1073. https://doi.org/10.1002/dvdy.24157

Mohamed, A.A.A., S. Ceunen, J.M.C. Geuns, W. Van den Ende and M. De Ley. 2011. UDPdependent glycosyltransferases involved in the biosynthesis of steviol glycosides. J. Plant Physiol., 168(10): 1136-1141. https://doi. org/10.1016/j.jplph.2011.01.030
Ramírez-Mosqueda, M.A. and L.G. IglesiasAndreu. 2016. Direct organogenesis of Stevia rebaudiana Bertoni using thin cell layer (TCL) method. Sugar Tech., 18(4): 424-428. https:// doi.org/10.1007/s12355-015-0391-0

Razak, U.N.A.A., C.B. Ong, T.S. Yu and L.K. Lau. 2014. In vitro micropropagation of Stevia rebaudiana Bertoni in Malaysia. Braz. Arch. Biol. Technol., 57(1): 23-28. https://doi. org/10.1590/S1516-89132014000100004

Shaw, J.E., R.A. Sicree and P.Z. Zimmet. 2010. Global estimates of the prevalence of diabetes for 2010 and 2030. Diabetes Res. Clin. Pract., 87(1): 4-14. https://doi.org/10.1016/j. diabres.2009.10.007

Standl, E., K. Khunti, T.B. Hansen and O. Schnell. 2019. The global epidemics of diabetes in the 21st century: Current situation and perspectives. Eur. J. Prev. Cardiol., 26: 7-14. https://doi. org/10.1177/2047487319881021

Yoneda, Y., H. Nakashima, J. Miyasaka, K. Ohdoi and H. Shimizu. 2017. Impact of blue, red, and far-red light treatments on gene expression and steviol glycoside accumulation in Stevia rebaudiana. Phytochemistry, 137:57-65.https:// doi.org/10.1016/j.phytochem.2017.02.002 